\section{Conclusions}

Intimate partner physical violence is highly prevalent in transitional Albania. The most empowered women are most likely to experience it and the least powerful men are most likely to perpetrate it. Men of rural origin are at increased risk of abusing their spouse in this country, which has experienced considerable internal migration in the past few years. Among the challenges for post-communist Albania, and its health professionals, is the need to reduce the prevalence of intimate partner violence, as well as to provide support for women who are in, or have been in, violent relationships and to be aware of the ways in which intimate partner violence influences psychological and physical health.

Contributors: GB and ER conceived the study and designed it with the help of SJ and UL. GB and ER conducted the study in Tirana. GB analysed the data and interpreted them with UL, VB, and RJ. GB and RJ wrote the draft of the paper and all other authors critically revised the draft of the paper for important intellectual content. All authors approved the final version of the manuscript. GB is guarantor.

Funding: Institute of Health Education and Human Welfare, Lublin, Poland.

Competing interests: None declared.

Ethical approval: Albanian Committee of Medical Ethics.

1 World Health Organization. World report on violence and health. Geneva: WHO, 2002. www.who.int/violence_injury_prevention/violence/ world_report/en/full_en.pdf (accessed 27 Jun 2005).

2 Watts C, Zimmerman C. Violence against women: global scope and magnitude. Lancet 2002;359:1232-7.

3 Campbell JC. Health consequences of intimate partner violence. Lancet 2002:359:1331-6.

4 Jewkes R. Intimate partner violence: causes and prevention. Lancet 2002;359:1423-9.
5 Rechel B, McKee M. Healing the crisis: a prescription for public health action in South Eastern Europe. New York: Open Society Institute Press, action

6 Nuri B, Tragakes E (eds). Health care systems in transition: Albania. Copenhagen: European Observatory on Health Care Systems, 2002 www.who.dk/document/E80089.pdf (accessed 11 Jul 2005).

7 Institute of Statistics of Albania. The population of Albania in 2001. Tirana: INSTAT, 2002.

8 Unicef. Multiple indicator cluster survey report. Tirana: UNICEF-Albania, 2000. www.childinfo.org/MICS2 /natlMICSrepz/Albania/mics_final_ report.pdf (accessed 5 Jan 2005).

9 Young A. Women who become men: Albanian sworn virgins. New York: Berg, 2001.

10 Pritchett Post SE. Women in modern Albania:first hand accounts of culture and conditions from over 200 interviews. London: McFarland, 1998.

11 Bourgois P. In search of respect: selling crack in El Barrio. Cambridge: Cambridge University Press, 1996.

12 Moore H. A passion for difference:essays in anthropology and gender. London: Polity Press, 1994.

13 Wood K, Jewkes R. "Dangerous" love: reflections on violence among Xhosa township youth. In: Morrell R, ed. Changing men in Southern Africa. Pietermaritzburg: University of Natal Press, 2001.

14 Strauss MA, Gelles RJ, Steinmetz SK. Behind closed doors: violence in the American family. New York: Anchor, 1980

15 Kantor GK, Jasinski, JL, Aldarondo E. Socio-cultural status and incidence of marital violence in Hispanic families. Violence Vict 1994;9:207-22. (Special issue: Violence against women of colour.)

16 Sorenson SB, Upchurch DM, Shen H. Violence and injury in marital arguments: risk patterns and gender differences. Am J Public Health 1996;86:35-40.

17 Martin SL, Tsui AO, Maitra K, Marinshaw R. Domestic violence in northern India. Am J Epidemiol 1999;150:417-26.

18 Kantor GK, Straus MA. Substance abuse as a precipitant of wife abuse victimizations. Am J Drug Alcohol Abuse 1989;15:173-89.

19 Jewkes R, Penn-Kekana L, Levin J. Risk factors for domestic violence: findings from a South African cross-sectional study. Soc Sci Med 2002; 55 : findings $1603-17$.

20 Ellsberg MC, Pena R, Herrera A, Liljestrand J, Winkvist A. Wife abuse among women of childbearing age in Nicaragua. Am J Public Health 1999;89:241-4.

21 Schuler SR, Hashemi SM, Riley AP, Akter S. Credit programmes, patriarchy and men's violence against women in rural Bangladesh. Soc Sci Med 1996;43:1729-42.

22 Hotaling GT, Sugarman DB. An analysis of risk markers in husband to wife violence: the current state of knowledge. Violence Vict 1986;1:101-24.

23 Ellsberg M, Heise L. Bearing witness: ethics in domestic violence research. Lancet 2002;359:1599-604.

\title{
Development of family medicine in Kosovo
}

Robert N Hedley, Bajram Maxhuni

Many eastern European countries are expanding primary care. Experience in Kosovo shows how some of the difficulties can be overcome

Eastern Europe's medical systems are changing in an attempt to match increasing health demands with limited resources. ${ }^{1}$ New methods of delivery and financing are being introduced, and the World Health Organization's regional office for Europe has been active in helping develop primary health care. ${ }^{2}$ We describe the evolution of primary care in Kosovo and the lessons for other post-communist countries.

\section{Development of health services}

Before 1989 inpatient services in Kosovo operated through six hospitals. Primary health care was delivered through large clinics (health houses) in 29 municipalities that oversaw a network of small clinics (ambulantas and punctas). The healthcare system relied heavily on specialists. Primary healthcare services were divided among subspecialties by age, sex, and disease type and provided by general practitioners and nurses. Patients presented to hospitals for both primary and secondary care. Private medical practice was not permitted.

Most Kosovar Albanians were dismissed from management and senior positions in all public services during 1990 to 1992 . The Mother Theresa Society set up a parallel primary healthcare system with 96 clinics throughout Kosovo, staffed and used by Albanian Kosovars. Private medical practice began to develop. A parallel system of medical education was also set up in these clinics and in private houses.

At the end of the war in Kosovo in 1999, the WHO assessed the health needs of Kosovo. The key recommendation was to strengthen and reorganise primary care. ${ }^{3}$ This principle was emphasised in the Health Policy for Kosovo, 2001, ${ }^{4}$ which recommended that patients should register with family doctors, with 2000 patients to each doctor plus two nurses, and that family doctors should also be personal doctors for first contact, having preventive as well as curative duties and acting as gatekeepers to secondary care. ${ }^{4}$
Hopwell House, Hopwell, Derbyshire DE72 3RU Robert Hedley adviser family medicine, Kosovo

Centre for the Development of Family Medicine, Pristina, Kosovo Bajram Maxhuni Kosovar family medicine programme manager

Correspondence to: R N Hedley rnhedley@aol.com

BMJ 2005;331:201-3 


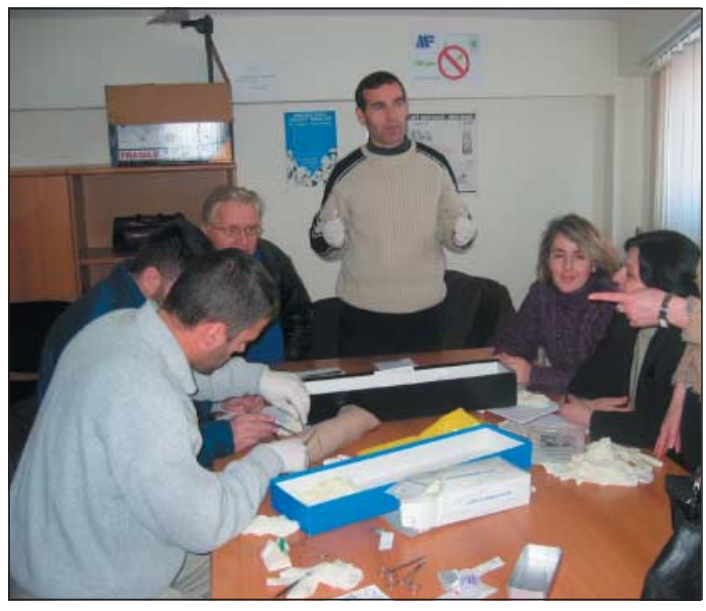

Small group teaching in Pristina family medical training centre

\section{Establishing an academic discipline of primary care}

The WHO working party recommended an education programme to improve the knowledge and skills of general practitioners. A course was developed, financed by the European Community Humanitarian Office, covering family medicine, child health, reproductive health, mental health, common illness in primary care, and common emergencies in primary care. One hundred doctors attended the first course, and 50 of them were selected to attend a course to become trainers. A family medicine training centre was established in each of the six regions for practical training, each one with a clinical skills laboratory.

These centres are now developing into learning practices and will be renamed family medicine learning centres. ${ }^{5}$ Doctors and nurses in each centre have begun working together on clinical guidelines and clinical audit. Each centre is visited by a quality assurance accreditation team to evaluate the structure and process of education and clinical care.

This WHO programme became the first year of a two year, fast track specialisation programme in family medicine, recognised by the Ministry of Health. The second year covered management of Kosovo's main health priorities (maternal and child health, prevention of heart and lung disease, tuberculosis, mental health, and quality of care), patient presentations, and the learning domains of family medicine (doctor-patient relationship, applied professional knowledge and skills, professional and ethical roles, organisational and legal aspects, population health). The course has been accredited by the Royal College of General Practitioners, and the college is helping to establish a three year course that will meet its requirements for international membership.

The European Agency for Reconstruction renovated a derelict building to house the family medicine unit in the university, with offices, lecture theatre, and seminar rooms. However, the university regulations would not allow teachers without an academic qualification to teach undergraduates. In total 21 candidates on the specialisation programme enrolled on a master of science (MSc) in family medicine, taught by Kosovar professors, international family medicine doctors, and medical educationalists from Nottingham University.
The family medicine unit has now become the Centre for the Development of Family Medicine with responsibility for developing academic family medicine as well as institutionalising family medicine across Kosovo.

The Association of Family Physicians of Kosovo has responsibility for continuing professional development. Doctors will be revalidated every five years, with assessment based on continuing professional development points and a personal portfolio containing clinical audit and a personal development plan.

Undergraduate teaching of family medicine started in 2004. Medical students now have six hours of lectures introducing them to the basic concepts of family medicine in their sixth year. All graduates now have to undertake a two year foundation module, the second year of which is in family medicine. A new undergraduate curriculum has been developed in which there will be a four week attachment to family medicine learning centres in the fourth year. Currently, the textbooks available are in English, but as English is becoming the country's second language an English curriculum may provide neutral ground for the different ethnic groups.

\section{Remaining problems}

Despite the progress in training family doctors, a national system of family medicine is not yet in place. Responsibility for primary care was passed to the municipalities in 2001 and progress varies between them. In hindsight, responsibility should have been retained at the centre so that changes could be implemented nationally. Patient lists have not yet been established, although in some regions patients are registered with a single family medicine centre. Similarly, media campaigns to raise awareness of the importance of family medicine have depended on local initiatives.

A new medical records system has been introduced, which will be linked to a central database. However, it is not always used appropriately because of insufficient training of staff. ${ }^{6}$

Ethnic tension is still causing difficulties. Violence erupts from time to time, particularly associated with the Serbian enclaves. For the most part Serbian doctors work in Serbian enclaves, some of them paid by Belgrade and with salaries higher than their counterparts in the rest of Kosovo, and indeed in Serbia. There is a Serbian hospital in Gracanica, which is only 10 miles from the University Hospital, Pristina. The hospital in Mitrovica is in a Serbian enclave. The main family medicine centre in Mitrovica doubles as a local hospital for Albanians, and those needing more specialised hospital treatment are moved to Pristina.

Only two Serbian doctors have attended the family medicine courses, and both left after two weeks because of pressure from other Serbians. Since then, course materials have been translated into Serbian and interest in these has been shown in some regions, particularly Gjilan. Perhaps in future a common interest in family medicine could be a catalyst for bringing together the different ethnic groups.

The poor salaries of doctors also threatens primary care. The average salary of a doctor is about $€ 200$ (£137, \$252) a month. Many doctors have at least two 
jobs. At least two doctors who have completed the training programme are now working exclusively in private practice. Unless salaries can be increased substantially, public sector doctors will continue to need to work in private practice. Safeguards will be needed to maintain recruitment to public services.

\section{Coordination of aid}

Perhaps the most important lesson from Kosovo's experiences is the need for coordination of resources. In 1999, many international organisations came to Kosovo with humanitarian aid. WHO set up a meeting between these organisations and staff in the Department of Health and Social Welfare, which later became the Ministry of Health. However, many of the organisations had to use their funds according to the wishes of their donors.

In 2002, Dartmouth Medical School, with a grant from the United States Agency for International Development (USAID), arrived in Gjilan to develop family medicine without consulting anyone in the ministry or the European Agency for Reconstruction. On the last day of their first visit they visited us in Pristina to discuss the fast track training programme. Since then we have worked closely with Dartmouth. When their first project on clinical microsystems ${ }^{7}$ had finished, Dartmouth, after discussion with us, wanted to roll out the results to the rest of Kosovo as part of a quality assurance programme. However, the donor insisted they work on a reproductive health project in one centre. In future, it would be more appropriate for donors to consider locally identified priorities.

Poor communication also led to misunderstandings. Cordaid, a Dutch non-governmental organisation sent a group of general practitioners on a course at Utrecht University for three months, but lack of coordination meant that these doctors missed the beginning of the WHO programme in Kosovo. Another problem is that much of the funding is for short term projects when long term investment is needed.

\section{Tensions within the health system}

Other specialists were sceptical about family medicine as an academic discipline and resented the family medicine unit's presence in the faculty building. The unit achieved a better working relationship with the dean and vice dean after a study tour to the United Kingdom, which convinced them of the value of family medicine and also the need for a university course for nurses. This study tour should have taken place much earlier. The dean became a strong ally in the reform process of medical education until he was asked to resign by the minister of education because of his age. The new dean so far is refusing to implement agreed reforms of the undergraduate curriculum.

Up to now primary care has had little if any gatekeeping role, and it is generally accepted that up to $80 \%$ of attendances at Pristina University Hospital could be dealt with in primary care. However, some hospital specialists see themselves in competition with family physicians, particularly when some of the patients can be redirected to their private rooms. Hospital specialists also resent the reallocation of resources

\section{Key lessons}

Coordination of donor activities is essential

Family medicine should be recognised as a specialty

Implementation of the primary healthcare system needs central coordination

National education campaigns for both the public and other healthcare professionals improve awareness and understanding

Local leadership and doctors' organisations should be empowered and involved from the beginning

to primary care. Presentations about family medicine have been set up across Kosovo, aimed at specialists, but this issue should have been tackled much earlier

\section{The future}

Throughout the four years of change family doctors in Kosovo have been encouraged and empowered, particularly through the Association of Family Physicians of Kosovo. Future academic leaders have been encouraged through the MSc programme. The director of health services at the Ministry of Health is a family physician, and more resources are being directed at primary care. However, in future family medicine in Kosovo may receive less international aid, particularly from the European Agency for Reconstruction, as other problems unfold across the world. A health insurance system needs to be set up, perhaps bolstered from Kosovo's consolidated budget, which is funded by taxation. An affordable and sustainable health system depends on the continued development of primary care.

Contributors and sources: RNH was formerly a general practitioner and regional director of postgraduate GP education for Trent. After retiring from the NHS he spent six months developing an undergraduate curriculum for family medicine in Malaysia. He has worked on developing family medicine in Kosovo for four years, initially for WHO and then for Bernard Brunhes International (BBI) and Health and Life Sciences Partnership (HLSP). BM is a family physician who has worked with several international organisations on the development of health programmes for Kosovo including WHO, BBI, and HLSP. RNH did the literature search, wrote the drafts for discussion with BM, produced the final article, and is the guarantor. Competing interests: None declared.

1 Smith T. European health care systems BMJ 1992;304:1457-9.

2 Grol R, Wensing M, Jacobs A, Baker R. The contribution of family doctors/general practitioners to health for all. Copenhagen: World Health Organization, 1992.

3 UN Civil Administration, Health and Social Services, Pristina. Interim health policy guidelines for Kosova and six month action plan. Pristina: UN Civil Administration, 1999.

4 Joint Interim Administrative Structure, Department of Health and Social Welfare. Health policy for Kosovo. Pristina: Department of Health and Social Welfare, 2001.

5 Carter Y, Jackson N, Bamfield A. The learning practice: a new model for primary health care teams. Educ Gen Pract 1998;9:182-7. 6 Simay AN, Hedley R, Maxhuni B. A survey of health professionals'

attitudes to family medicine in 2003. Praxis Medica Kosova 2004;46:135-8. Learning from high performing front line clinical units. Jt Comm J Qual Improv 2002;28:472-93. 